\title{
Race diversity in dryland maize (Zea mays L.) landraces from southern Nuevo León, México
}

Lugo-Cruz, Eleazar ${ }^{1}$; Mendoza-Onofre, Leopoldo E. ${ }^{2}$; Santacruz-Varela, Amalio ${ }^{3}$; Gutiérrez-Espinosa, Ma. Alejandra ${ }^{4}$; Hernández-Casillas, Juan M. ${ }^{5}$; Zavala-García, Francisco ${ }^{6}$; González-Hernández, Victor A. ${ }^{1 *}$

Departamentos de ${ }^{1}$ Fisiología Vegetal, ${ }^{2}$ Producción de Semillas, ${ }^{3}$ Genética, y ${ }^{4}$ Fruticultura, Colegio de Postgraduados, Campus Montecillo. Carretera México-Texcoco km 36.5, Montecillo, Texcoco, Estado de México, México. ${ }^{5}$ Campo Experimental del Valle de México, Instituto Nacional de Investigaciones Forestales, Agrícolas y Pecuarias. Carretera Texcoco-Los Reyes Km.13.5, Coatlinchán, Texcoco, Estado de México. ${ }^{6}$ Facultad de Agronomía, Universidad Autónoma de Nuevo León, General Escobedo, Nuevo León, México.

*Corresponding author: vaghacolpos. $\mathrm{mx}$

\section{ABSTRACT}

Objective: To analyze the race diversity and geographic distribution of the native maize landraces currently cropped at southern Nuevo León, México.

Design/Methodology/Approach: Data was obtained from 41 accessions which represent the commercial production in the dry land area, where fertilization and pest control are scarcely used. Landraces were classified according to the CONABIO guidelines for ear traits.

Results: The measured accessions correspond to seven maize races and to seven interracial crosses. The two most frequent maize races were Ratón and Cónico Norteño, mainly located in the dry areas with less rain.

Study Limitations/Implications: Three races, Celaya, Tablilla de Ocho and Elotes Cónicos, had not been previously reported; while two formerly reported races Tabloncillo and Olotillo, were no longer found. This study did not include the grain-colored accessions.

Findings/Conclusions: Three collections stood out for producing large cobs with large kernels, thus showing a high yield potential. The maize landraces harvested in dryland areas might offer advantages to be grown under harsh environments or be used as gene donors for drought tolerance.

Key words: ear diversity, native maize, race, dryland, Zea mays.

\section{INTRODUCTION}

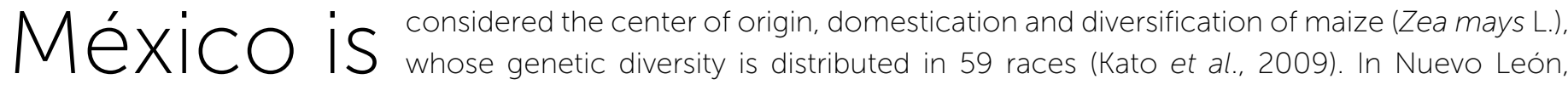
maize landraces are located in marginalized dryland zones such as the Sierra Madre Oriental (Acosta-Díaz et al., 2014). In this region maize constitutes $93 \%$ of the cultivated dryland surface, with a kernel yield that ranges between 0.34 and $1.1 \mathrm{t} \mathrm{ha}^{-1}$ (SIAP, 2019). Acosta-Díaz et al. (2014) detected the presence of five races in this region: Cónico Norteño, Olotillo, Ratón, Tuxpeño, and Tuxpeño Norteño. But there are still unexplored zones in the region, such

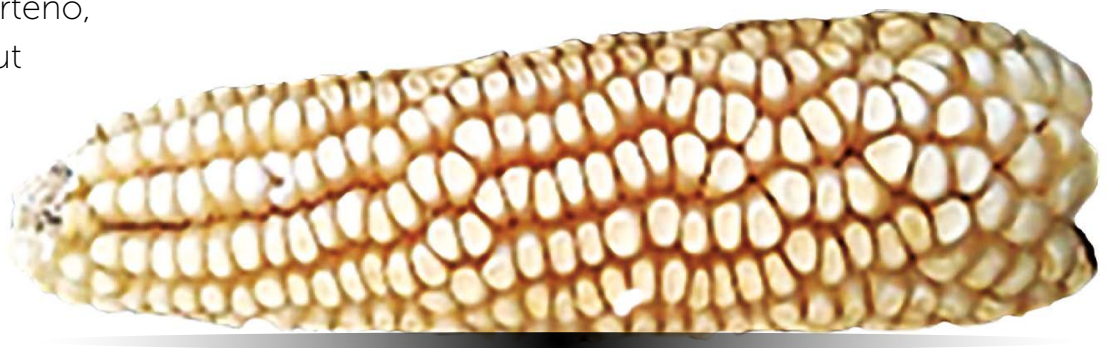


as the Gral. Zaragoza municipality, where in 2019 there were still no records of native maize varieties (CONABIO, 2019).

Studying native maize is important to ensure its survival; to understand its genetic diversity and geographic distribution; to maintain successful production processes, understanding the form, speed and causes of genetic erosion; and to plan strategies for its use and conservation (Dwivedi et al., 2016; Azeez et al., 2018). Currently, global climate change emphasizes the need to use genotypes that are better adapted to unfavorable climates, and the native varieties can contain adaptation genes to such marginal conditions (Hellin et al., 2014). Here, the diversity and distribution of native maize landraces was explored in drylands of southern Nuevo León, México, to classify races by cob type and to identify outstanding germplasm for use in maize plant breeding programs.

\section{MATERIALS AND METHODS}

In February 2016, native maize samples were collected from 41 localities in the Sierra Madre Oriental region located in the south of Nuevo León state, México, with differences in climate, altitude, and geographic location (Figure 1).

Forty maize cobs per accession were collected, taken from the plot or warehouse of one producer per locality, except in the communities of Carpintería and Refugio, where the producers had already de-kernelled the corn, so therefore only $1.0 \mathrm{~kg}$ of grain and less than five cobs were collected from each community. This sample size was considered sufficient for the race classification of the cobs, but insufficient to be included in the statistical analysis of cob diversity. In each collection, information from the production unit was registered based on the Passport Sheet for the Collection of Native Maize (CONABIO, 2019).

The diversity analysis was carried out in $n=10$ cobs, representative of each of the 39 accessions. Each cob was measured for: diameter (ED, $\mathrm{mm}$ ), longitude ( $E L$, $\mathrm{cm})$, weight (EW, g), cob diameter $(\mathrm{mm})$, number of rows (NR), kernels per row (KR), number of total kernels (product of NR $\times$ KR), total grain weight (TGW, g),

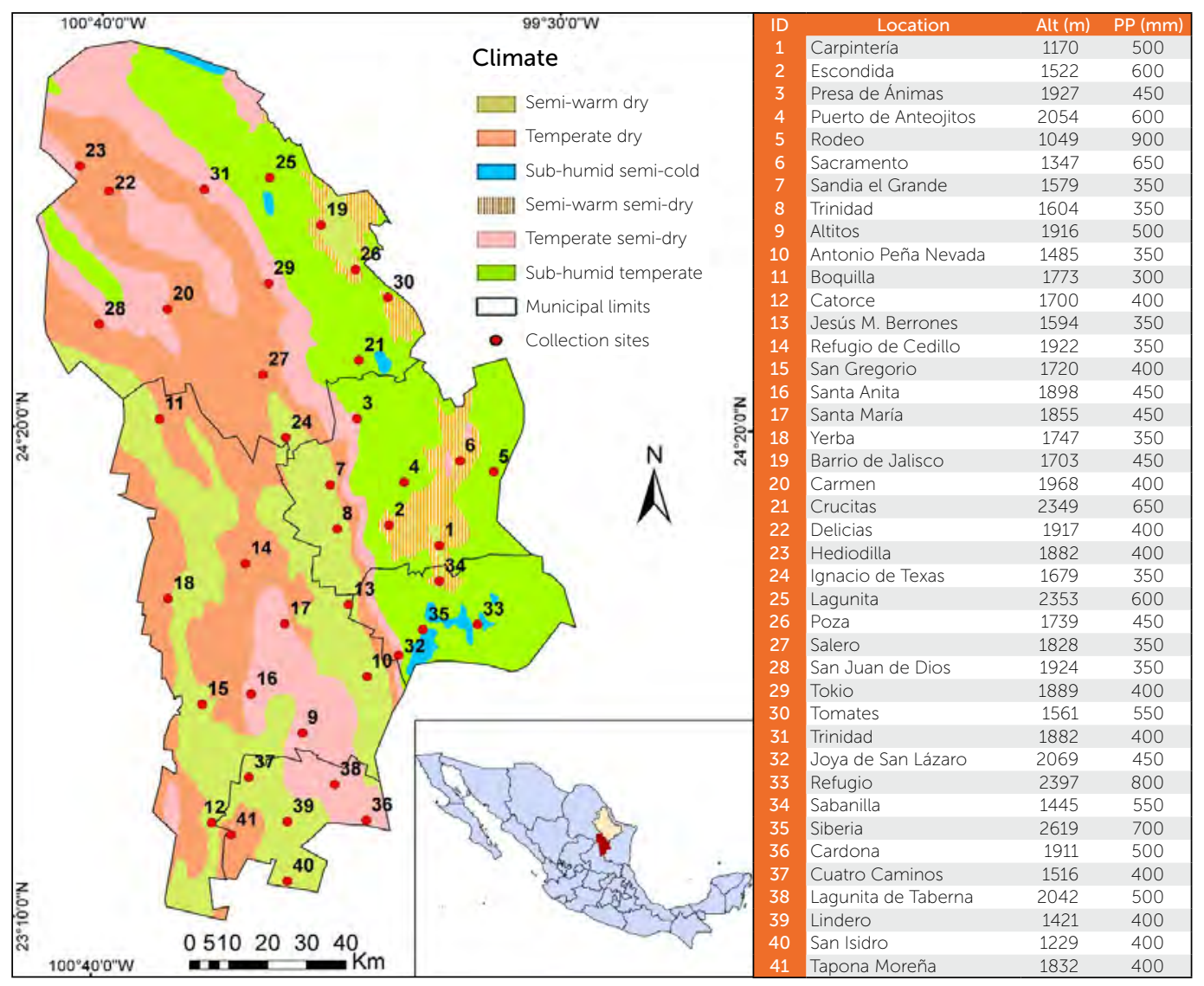

Figure 1. Geographic location of 41 Creole corn accessions from Nuevo León, Mexico. ID: Accession number Alt: Altitude. PP: Annual precipitation. Map source and climates: INEGI (2019). 
weight of 100 kernels (g), percentage of de-kernelling (TGW/EW ratio, multiplied by 100 ) and the ED/EL ratio. Furthermore, qualitative variables were measured such as cob shape, arrangement of rows, type and color of kernel, and cob color, based on the Practical Guide for the Preliminary Description of Native Maize Collections (CONABIO, 2019).

The information about the production units was reported in units of relative frequency with regard to the total of interviewed producers. With the accession averages of each quantitative variable, a cluster analysis was performed by using a Euclidian distances matrix and the unweighted pair group method with arithmetic mean (UPGMA) (Gan et al., 2007). The optimal number of clusters was determined with the "NbClust" function (Charrad et al., 2014) of the R program (R Core Team, 2019). The variability between groups of accessions resulting from the cluster analysis was determined by means of an analysis of variance according to a completely randomized design where the number of repetitions corresponded to the number of accessions per group or subgroup. The multiple means comparison was done with Tukey's test ( $p \leq 0.05)$, using the SAS 9.4 software (SAS Institute, 2015).

\section{RESULTS AND DISCUSSION}

\section{Characteristics of production systems}

Producers in southern Nuevo León sow maize seeds between February and July and harvest between June and November. They are unaware of the phenology of their varieties and the average grain or fodder yields they produce, because these characteristics vary from year to year depending on the amount of rainfall during the cultivation cycle. Maize grain is mainly destined for selfconsumption, and surpluses are sold locally (Table 1). Maize is grown alone or in association with squash (Cucurbita pepo), pea (Pisum sativum) or bean (Phaseolus vulgaris).

It is notable that $93 \%$ of producers are over the age of 40 , and $40 \%$ are over 60 years of age. This proportions are worrying, as in the rest of the country, because only growers under 40 (7\%) will remain as custodians of the diversity of maize, and this situation puts at risk the conservation and evolution of native maize. Young people's low interest in maize production in the drylands can be attributed to the low or null profitability, derived from low yields and low-tech production systems, as $42 \%$ of growers use animals for farm labor, 56\% plant in monoculture, $80 \%$ report pest problems in storage and none of them have a pest control plan, and $92 \%$ of them do not fertilize.

\section{Race classification}

In the 41 native maize accessions, six pure races were identified (Table 2 and Figure 2), which represented $63 \%$ of collected samples, and one interracial combined race. The interracial crosses represented $37 \%$ of the total collected samples (Table 2 and Figure 3). These results show the importance of interracial combinations which contribute to the genetic recombinations ocurring through the flow of pollen and the exchange of seeds between growers (Martínez-Sánchez et al., 2017), which could also imply the development of new germplasm with different characteristics from those of the pure races (Acosta-Díaz et al., 2014).

Other than the four landraces (Cónico Norteño, Ratón, Tuxpeño and Tuxpeño Norteño) that had previously been reported in this region, Celaya and Tablilla de Ocho were found to be pure races, as well as Elotes Cónicos crossed 
with Cónico Norteño, which had not been identified in previous collections (AcostaDíaz et al., 2014; CONABIO, 2019). Conversely, this time the Tabloncillo and Olotillo landraces were not found, which had previously been reported in the studied zone (Acosta-Díaz et al., 2014; CONABIO, 2019). It is possible that a loss of germplasm has occurred in the last few years, but a more precise verification of this would be needed.

In terms of the geographic location of the landraces, Ratón and Celaya were found primarily in arid and semi-arid climates with low annual precipitation (from 300 to $550 \mathrm{~mm}$ ), and in altitudes between 1445 and 2069 m. The Cónico Norteño landrace was found in a broader range of altitudes (from 1170 to $2619 \mathrm{~m}$ ) and of rainfall (from 350 to $800 \mathrm{~mm}$ ), with presence in the six climates of the region, which suggests ample environmental adaptability of this landrace. The two most abundant landraces in the area were Ratón and Cónico
Table 2. Six landraces and seven inter-racial crosses detected in 41 native maize accessions from the dryland region in Southern Nuevo León state, México.

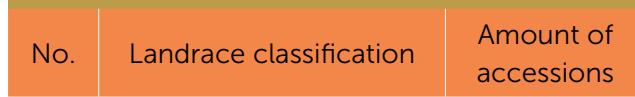

\begin{tabular}{c|l|c}
\multicolumn{2}{|c}{ Races } \\
\hline 1 & Ratón & 8 \\
\hline 2 & Tuxpeño & 6 \\
\hline 3 & Cónico Norteño & 3 \\
\hline 4 & Tuxpeño Norteño & 3 \\
\hline 5 & Celaya & 1 \\
\hline 6 & Tablilla de Ocho \\
\hline
\end{tabular}
Inter-racial crosses

\begin{tabular}{l|l|c}
\hline 1 & $\mathrm{CN} \times \mathrm{R} / \mathrm{R} \times \mathrm{CN}$ & 5 \\
\hline 2 & $\mathrm{R} \times \mathrm{C} / \mathrm{C} \times \mathrm{R}$ & 3 \\
\hline 3 & $\mathrm{CN} \times \mathrm{TN}$ & 3 \\
\hline 4 & $\mathrm{CN} \times \mathrm{C}$ & 1 \\
\hline 5 & $\mathrm{CN} \times \mathrm{EC}$ & 1 \\
\hline 6 & $\mathrm{R} \times \mathrm{TN}$ & 1 \\
\hline 7 & $\mathrm{R} \times \mathrm{T}$ & 1 \\
\hline C: Celaya, CN: Cónico Norteño, R: Ratón, T: \\
Tuxpeño, TN: Tuxpeño Norteño, EC: Elotes \\
Cónicos.
\end{tabular}

Norteño, both in pure races and interracial crosses, present in 44 and $36 \%$ of all the collected accessions, respectively. It had previously been reported that these two landraces are the ones preferred by the region's producers, due to their ample adaptability to conditions of limited precipitation, extreme temperatures, and different altitudes, to their short growth cycle and to their use for tortillas and other masa-derived products (Reveles-Torres et al., 2014; CONABIO, 2019).

The seven maize landraces detected in this study correspond to an intermediate diversity, compared to that reported in Quintana Roo, Yucatán, Baja California Sur, Tlaxcala, Campeche, and Tabasco, where three to four varieties have been identified per entity. In contrast, in states with high maize diversity, 22 (Veracruz), 21 (Michoacán) and 17 (in Oaxaca and in Jalisco) landraces have been identified (Lazos and Chauvet, 2012).
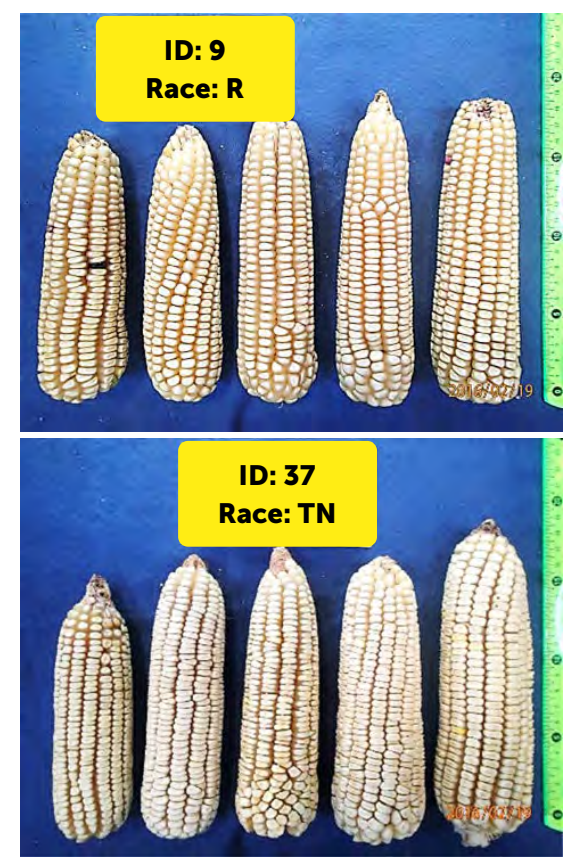

Figura 2. Cobs of races identified in native m Cónico Norteño, TN: Tuxpeño Norteño, C: Celaya y TO: Tablilla de ocho.
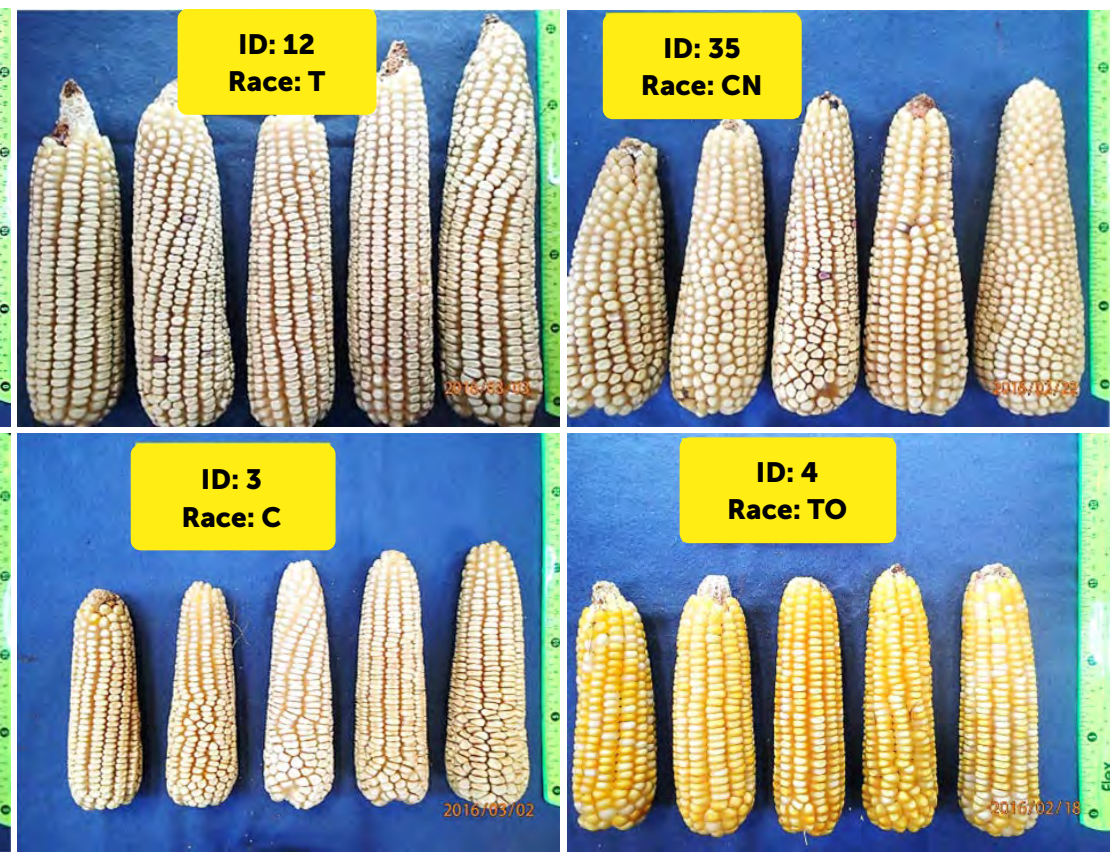

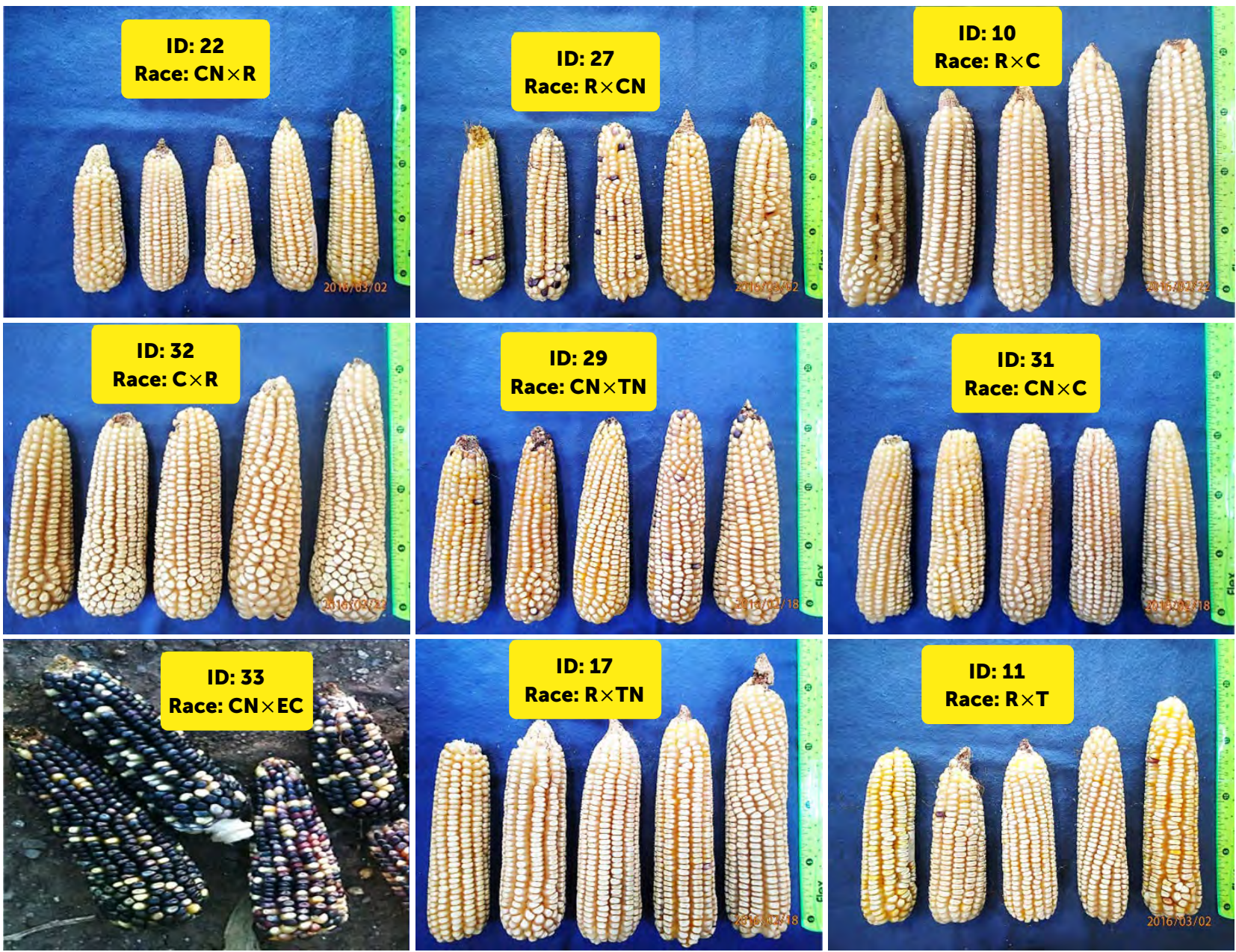

Figura 3. Cobs of interracial crosses identified in native maize (Zea mays L.) from southern Nuevo León, México. R: Ratón, T: Tuxpeño, CN: Cónico Norteño, TN: Tuxpeño Norteño, C: Celaya, y EC: Elotes Cónicos.

Characteristics of the cobs. Two accession groups were identified in the cobs. The first (G1) was formed by 20 accessions with two sub-groups, SG1-1 and SG1-2; the second (G2) was established by 19 accessions with three subgroups, SG2-1, SG2-2 and SG2-3 (Figure 4).
G2 presented greater values in quantitative values of the cobs (except in ED/EL), with 20\% more cobs with straight rows and 12\% more of the dent variety of kernels, compared to G1 (Table 3). In the sub-groups, the greatest contrasts were found between SG2-2 and

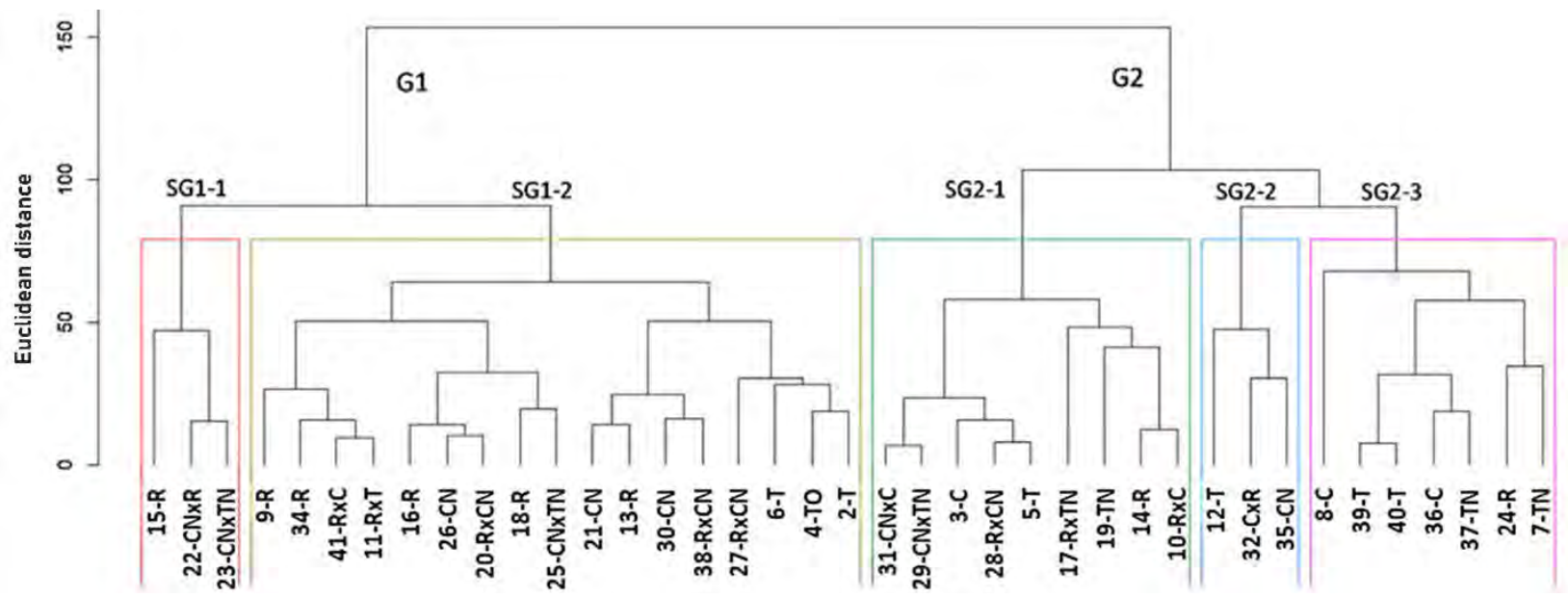

Figure 4. Dendrogram of the grouping of 39 accessions of corn (Zea mays L.), obtained by the UPGMA method. The name includes the collection number and racial classification identified in Figure 1. G = group. SG = subgroup. 
Table 3. Relative frequency (\%) of quantitative and qualitative traits of maize ears classified in two groups and five subgroups of landraces grwon at Southern región of Nuevo León state, México

\section{Cob characteristic}

Quantitative traits

Diameter (mm)

Length $(\mathrm{cm})$

Weight (g)

Cob diameter ( $\mathrm{mm}$ )

Rows per ear

Kernel number per row

Kernel number per ear

Total kernel weight (g)

Weight 100 grains (g)

Per cent of kernels (\%)

Diameter/length ratio

Shape

Row arrangement

Kernel type

Qualitative traits

\begin{tabular}{|l|r|}
\hline Conical & 6.8 \\
\hline Conical- cylindrical & 73.2 \\
\hline
\end{tabular}

\begin{tabular}{l|l} 
Cylindrical & 20.0 \\
\hline
\end{tabular}

\begin{tabular}{|l|r}
\hline Regular & 72.2 \\
\hline Irregular & 0.5 \\
\hline
\end{tabular}

\begin{tabular}{|l|r|}
\hline Irregular & 0.5 \\
\hline Straight & 26.8 \\
\hline
\end{tabular}

\begin{tabular}{l|l}
\hline Helicoidal & 0.5 \\
\hline
\end{tabular}

\begin{tabular}{l|l} 
Floury & 0.0 \\
\hline
\end{tabular}

\begin{tabular}{|l|r|}
\hline Floury & 0.0 \\
\hline Dent & 12.6 \\
\hline
\end{tabular}

\begin{tabular}{|l|r|}
\hline Semi-dent & 44.2 \\
\hline Semi-flint & 41.6 \\
\hline
\end{tabular}

\begin{tabular}{|c|c|c|c|}
\hline & \multirow{2}{*}{ Semi-flint } & \multirow[b]{2}{*}{41.6} & \multirow[b]{2}{*}{21.} \\
\hline & & & \\
\hline & Flint & 1.6 & \\
\hline \multirow{3}{*}{ Kernel color } & White & 82.1 & \\
\hline & Pale yellow & 5.3 & \\
\hline & Yellow & 12.6 & \\
\hline \multirow{2}{*}{ Cob color } & White & 87.4 & \\
\hline & Red & 12.6 & \\
\hline
\end{tabular}

G: group; SG: subgroup. Different capital letters in a row mark significant differences between the two groups; different letters in a row mark significant differences among the five subgroups (Tukey, $p \leq 0.05$ ).

SG1-1; sub-group SG2-2 consisted of Catorce (Tuxpeño) Joya de San Lázaro (Celaya x Ratón) and Siberia (Cónico Norteño), and presented higher values in cob size, but not in DESG or ED/EL, as well as a higher proportion of conical shaped cobs, with straighter rows, dent and semi-dent kernels, compared to sub-group SG1-1.

The number and weight of kernels per cob are components of yield, and as such they are useful characteristics to consider in genetic plant breeding (Pecina et al., 2011). Sub-groups SG2-2 and SG2-3 are the ones with the highest number of kernels per cob
Subgroups

\begin{tabular}{|c|c|c|c|c|}
\hline SG1-1 & SG1-2 & SG2-1 & SG2-2 & SG2-3 \\
\hline $38.5 d$ & $41.3 c$ & $43.2 c$ & $49.5 a$ & $46 b$ \\
\hline $13.3 c$ & $15.1 \mathrm{~b}$ & $15.9 \mathrm{~b}$ & $18.2 \mathrm{a}$ & $15.8 \mathrm{~b}$ \\
\hline $95.1 \mathrm{~d}$ & $139 \mathrm{c}$ & $165 b$ & $245 a$ & $182 \mathrm{~b}$ \\
\hline $20.5 c$ & $22.1 \mathrm{bc}$ & $22.9 b$ & $25.1 \mathrm{a}$ & $23.6 \mathrm{ab}$ \\
\hline $12.4 \mathrm{c}$ & $12.4 \mathrm{C}$ & $13.6 \mathrm{~b}$ & $14.7 \mathrm{ab}$ & $14.9 a$ \\
\hline $29.1 \mathrm{C}$ & $34.1 \mathrm{~b}$ & $36.8 \mathrm{ab}$ & $37.8 \mathrm{a}$ & 39.4 a \\
\hline $363 d$ & $421 \mathrm{c}$ & $502 b$ & $550 \mathrm{a}$ & $586 a$ \\
\hline $87 d$ & $119 c$ & $144 \mathrm{~b}$ & $206 a$ & $160 \mathrm{~b}$ \\
\hline $24.5 c$ & $29.2 b$ & $30.0 \mathrm{~b}$ & $40.6 \mathrm{a}$ & $28.9 \mathrm{~b}$ \\
\hline $84.5 \mathrm{a}$ & 85.7 a & $87.2 \mathrm{a}$ & $84.7 \mathrm{a}$ & $88 \mathrm{a}$ \\
\hline $2.9 \mathrm{a}$ & $2.7 \mathrm{a}$ & $2.7 \mathrm{a}$ & $2.7 \mathrm{a}$ & $2.9 \mathrm{a}$ \\
\hline SG1-1 & SG1-2 & SG2-1 & SG2-2 & SG2-3 \\
\hline 33.3 & 1.9 & 1.1 & 33.3 & 11.4 \\
\hline 50.0 & 77.5 & 77.8 & 46.7 & 58.6 \\
\hline 16.7 & 20.6 & 21.1 & 20.0 & 30.0 \\
\hline 90.0 & 68.8 & 48.9 & 83.3 & 55.7 \\
\hline 0.0 & 0.6 & 3.3 & 0.0 & 1.4 \\
\hline 10.0 & 30.0 & 46.7 & 16.7 & 42.9 \\
\hline 0.0 & 0.6 & 1.1 & 0.0 & 0.0 \\
\hline 0.0 & 0.0 & 0.0 & 0.0 & 1.4 \\
\hline 0.0 & 15.0 & 12.2 & 33.3 & 42.9 \\
\hline 53.3 & 42.5 & 45.6 & 56.7 & 55.7 \\
\hline 46.7 & 40.6 & 42.2 & 10 & 0.0 \\
\hline 0.0 & 1.9 & 0.0 & 0.0 & 0.0 \\
\hline 66.7 & 85 & 94.4 & 100 & 100 \\
\hline 33.3 & 0.0 & 0.0 & 0.0 & 0.0 \\
\hline 0.0 & 15.0 & 5.6 & 0.0 & 0.0 \\
\hline 86.7 & 87.5 & 78.9 & 83.3 & 85.7 \\
\hline 13.3 & 12.5 & 21.1 & 16.7 & 14.3 \\
\hline
\end{tabular}

(550 and 586, respectively), and SG2-2 is the one with the largest kernels and greater weight of grain per cob. The SG2-2 accessions were collected in localities with higher altitude (2129 $\mathrm{m}$ ) and annual precipitation (517 $\mathrm{mm}$ ), where the most favorable environments are and where a greater yield is harvested.

The differences $(p \leq 0.05)$ between race groups in terms of cob characteristics indicate that such traits were useful for exploring and analyzing the diversity of native maize landraces. The results obtained confirm that the selection made by the farmers themselves has improved these 
and other characteristics of the maize by giving rise to varieties suitable for production in these environments, as proposed by Hortelano et al. (2012).

\section{CONCLUSIONS}

Among native maize of southern Nuevo León, there is diversity in races and cob characteristics. Seven landraces have been identified: Celaya, Cónico Norteño, Ratón, Tuxpeño, Tuxpeño Norteño, Tablilla de Ocho and Elotes Cónicos. The races with the most accessions in the region were Ratón and Cónico Norteño, especially in the regions with less rainfall. Three landraces (Celaya, Tablilla de Ocho and Elotes Cónicos) had not been reported in previous collections. Three collections stand out for having large cobs with the large kernels (Catorce [Tuxpeño race], Joya de San Lázaro [a cross between races Celaya $\times$ Ratón], and Siberia (Cónico Norteño race), with the potential for high grain yield production The varieties of native maize from southern Nuevo León are grown in marginal conditions and can offer advantages as genetic sources of adaptability to drought and other adverse environments.

\section{REFERENCES}

Acosta-Díaz, E., Zavala-García, F., Valadez-Gutiérrez, J., HernándezTorres, I., Amador-Ramírez, M. D., \& Padilla-Ramírez, J. S. (2014). Exploración de germoplasma nativo de maíz en Nuevo León, México. Revista Mexicana de Ciencias Agrícolas 8: $1477-$ 1485

Azeez, M. A., Adubi, A. O., \& Durodola F. A. (2018). Landraces and crop genetic improvement. In: O. Grillo (Eds.). Rediscovery of Landraces as a Resource for the Future (pp: 1-19). IntechOpen London. doi: https://doi.org/10.5772/ intechopen.75944

Charrad, M., Ghazzali, N., Boiteau, V., \& Niknafs, A. (2014). NbClust: An $\mathrm{R}$ package for determining the relevant number of clusters in a data set. Journal of Statistical Software 61: 1-36. doi: 10.18637/ jss.v061.i06

CONABIO, Comisión Nacional para el Conocimiento y Uso de la Biodiversidad. (2019). Proyecto global de maíces nativos Razas de maíz de México. Base de datos 2017. Anexo 7: guía de colecta. Anexo 12: exploración y colecta. Recuperado de https://www.biodiversidad.gob.mx/genes/proyectoMaices html

Dwivedi, S. L., Ceccarelli, S., Blair, M. W., Upadhyaya, H. D., Are, A. K., \& Ortiz R. (2016). Landrace germplasm for improving yield and abiotic stress adaptation. Trends in Plant Science 21: 31-42. doi: https://doi.org/10.1016/j.tplants.2015.10.012

Gan, G., Ma, C. \& Wu, J. (2007). Data Clustering: Theory, Algorithms, and Applications. ASA-SIAM Series on Statistics and Applied Probability, SIAM, Philadelphia, ASA, Alexandria, Virginia, EUA

Hellin, J., Bellon, M. R., \& Hearne, S. J. (2014). Maize landraces and adaptation to climate change in Mexico. Journal of Crop Improvement 28: 484-501. doi: https://doi.org/10.1080/1542 7528.2014 .921800
Hortelano-Santa, R., Gil-Muñoz, A., Santacruz-Varela, A., H. LópezSanchez, H., López-Antonio P., \& Miranda-Colín, S. (2012). Diversidad fenotípica de maíces nativos del altiplano centrooriente del estado de Puebla, México. Revista Fitotecnia Mexicana 35: 97-109

Kato-Yamakake, T. A., Mapes-Sanchez, C., Mera-Ovando, L. M. Serratos-Hernández, J. A., \& Bye-Boettler, R. A. (2009). Origen y Diversificación del maíz: Una Revisión Analítica. Universidad Nacional Autónoma de México, Comisión Nacional para el Conocimiento y Uso de la Biodiversidad. México, D. F. 116 p.

Lazos, E., \& Chauvet, M. (2012). Análisis del contexto social y biocultural de las colectas de maíces nativos en México. Proyecto global de maíces nativos. Comisión Nacional para el Conocimiento y Uso de la Biodiversidad. México. 533 p. Rescatado de: https:// www.biodiversidad.gob.mx/media/1/genes/files/analisis_ socio_cultural_maices.pdf

Martínez-Sánchez, J., Espinosa-Paz, N., \& Cadena-Iñiguez, P. (2017). Caracterización morfológica de poblaciones de maíz nativo (Zea mays L.) en Chiapas, México. Agroproductividad 10: 26 33.

Pecina-Martínez, J. A., Mendoza-Castillo, M. C., López-Santillan, J. A., Castillo-González, F., Mendoza-Rodriguez, M., \& OrtizCereceres, J. (2011). Rendimiento de grano y sus componentes en maíces nativos de Tamaulipas evaluados en ambientes contrastantes. Revista Fitotecnia Mexicana 34: 85-92.

R Core Team. 2019. R: A Language and environment for statistical computing. Version 3.6.1. Foundation for Statical Computing

SAS Institute (2015). Statistical analysis software for Windows version 9.4. Cary, North Carolina, USA: SAS Institute.

SIAP, Servicio de información agroalimentaria y pesquera. (2019) Avance de siembras y cosechas. Secretaría de Agricultura y Desarrollo Rural. Ciudad de México. Rescatado de: http:// infosiap.siap.gob.mx:8080/agricola_siap_gobmx/Resumen Delegacion.do

Reveles-Torres, L. R., Luna-Flores, M., Mejia-Gurrola, A., HernándezMartínez J., \& García-Hernández, S. (2014). Razas actuales de maíz de secano en el estado de Zacatecas, México. Revista Mexicana de Ciencias Agrícolas 5: 1155-1168

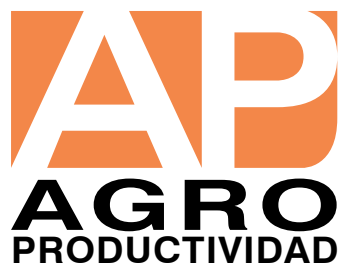

